\title{
Genetic insights into the modification of the pre-fertilization mechanisms during plant domestication
}

\author{
Silvia Manrique ${ }^{1,(\mathbb{D})}$, James Friel ${ }^{2,3}$, Pietro Gramazio ${ }^{4,5,}$, Tomas Hasing $^{3}$, Ignacio Ezquer, ${ }^{1}$ and \\ Aureliano Bombarely ${ }^{1,3, *, \text {, }}$ \\ ${ }^{1}$ Department of Biosciences, Università degli Studi di Milano, Milan, Italy \\ ${ }^{2}$ Genetics and Biotechnology Laboratory, Plant and AgriBioscience Research Center (PABC), Ryan Institute, National University of \\ Ireland Galway, Galway, Ireland \\ ${ }^{3}$ School of Plant and Environmental Sciences (SPES), Virginia Tech, Blacksburg, VA, USA \\ ${ }^{4}$ Instituto de Conservación y Mejora de la Agrodiversidad Valenciana (COMAV), Universitat Politècnica de València, Valencia, Spain \\ ${ }^{5}$ Faculty of Life and Environmental Sciences, University of Tsukuba, Tsukuba, Japan \\ *Correspondence: aurebg@vt.edu
}

Received 25 December 2018; Editorial decision 2 May 2019; Accepted 2 May 2019

Editor: Sílvia Coimbra, University of Porto, Portugal

\begin{abstract}
Plant domestication is the process of adapting plants to human use by selecting specific traits. The selection process often involves the modification of some components of the plant reproductive mechanisms. Allelic variants of genes associated with flowering time, vernalization, and the circadian clock are responsible for the adaptation of crops, such as rice, maize, barley, wheat, and tomato, to non-native latitudes. Modifications in the plant architecture and branching have been selected for higher yields and easier harvests. These phenotypes are often produced by alterations in the regulation of the transition of shoot apical meristems to inflorescences, and then to floral meristems. Floral homeotic mutants are responsible for popular double-flower phenotypes in Japanese cherries, roses, camellias, and lilies. The rise of peloric flowers in ornamentals such as snapdragon and florists' gloxinia is associated with non-functional alleles that control the relative expansion of lateral and ventral petals. Mechanisms to force outcrossing such as self-incompatibility have been removed in some tree crops cultivars such as almonds and peaches. In this review, we revisit some of these important concepts from the plant domestication perspective, focusing on four topics related to the pre-fertilization mechanisms: flowering time, inflorescence architecture, flower development, and pre-fertilization self-incompatibility mechanisms.
\end{abstract}

Keywords: Clonal propagation, domestication, flower development, flowering time, inflorescence architecture, selfincompatibility, sexual reproduction.

\section{Introduction}

Plant domestication is the process of adapting plants to human use by selecting specific traits. Domestication can also be understood as the process of selection of crucial traits by early farmers (domestication syndrome), being different from crop improvement, a later process where secondary traits are selected.
For this review, we have preferred to use domestication as a synonym of human-driven active selection of useful (or desirable) traits. Under this definition, domestication can be understood as a continuous process ranging from the active growing of a wild plant with a specific goal (pre-domestication) to their 
genetic modification by modern techniques such as CRISPR (clustered regularly interspaced short palindromic repeats; molecular breeding).

Many traits selected during domestication are related to plant reproduction, since most plant-derived food is the product of plant reproduction (seeds and fruits). Plant reproduction is frequently altered in the case of ornamental plants too, as often the targets of the selection are the flowers.

Charles Darwin was one of the first scientists to study the phenotypic changes related to the domestication process. The first chapter of his book 'On the origin of species' introduced several ideas about domestication such as the increase in phenotypic diversity and the pushing of the reproductive barriers during domestication (Darwin, 1859). Then, 9 years later in his book 'The variation of animals and plants under domestication', Darwin developed his ideas and observations about domestication in greater detail. Chapters X and XI summarize Darwin's observations on the variation of flowers, buds, and reproduction modes (Darwin, 1868). He described floral homeotic mutations in which stamens and pistils are converted to petals for species such as Aquilea vulgaris (columbine) and Primula vulgaris (hose-in-hose primroses), respectively. $\mathrm{He}$ also mentioned a poppy variety in which stamens have turned into pistils. DeVries (1904) also shared this observation in his book 'Species and varieties, their origin by mutation' where he pointed to this phenotype in the species Papaver commutatum. Another change in flower morphology described by Charles Darwin was the transition from zygomorphic to actinomorphic (peloric) flowers in Sinningia speciosa (gloxinia) and Antirrhinum majus (snapdragon). Darwin's observations exemplify some of the changes in the reproductive mechanisms which occurred during the plant domestication process, but they are not the only ones. Changes in the transition from the vegetative to the reproductive phase, the fertilization process, fruit development, ripening, and abscission are also commonly associated with plant domestication. In this review, we present important examples of the alteration of these mechanisms. Due to space constraints, we will focus on the events occurring prior to the fertilization of the ovule: transition of the vegetative to the reproductive phase, inflorescence architecture and flower development, and self-incompatibility (SI). We summarize the main genes described in this article in Table 1.

\section{Changes in flowering time associated with plant domestication}

The transition from the vegetative to the reproductive stage is controlled by a complex genetic mechanism that translates changes in photoperiod, temperature, and plant hormones into the signal that induces the production of flowers. The plant domestication process involved the adaptation of human-selected populations to environments with different photoperiods and temperatures, which involves the selection of changes in the flowering time of these species. The genetic mechanisms that control flowering time have been extensively studied in several plant species, but most of the work has been done in the model species Arabidopsis thaliana, a long-day plant native to Africa and Eurasia. Hundreds of genes have been described in the flowering time pathway, but, due to space constraints, we will focus on listing genes that have been selected during domestication without giving extensive detail about the pathways, as this has already been reviewed in many excellent articles.

The central player controlling flowering time is the FLOWERING LOCUS T gene (FT), which encodes a small phosphatidylethanolamide-binding protein (PEBP) that binds to phospholipids (Kobayashi et al., 1999). FT is expressed in leaves and is induced by long-day treatment. FT is translocated to the shoot apex where it induces its own expression and activates the expression of floral determination genes to trigger flowering (Wigge et al., 2005; Corbesier et al., 2007).

Photoperiod is the most important environmental signal determining flowering time. In Arabidopsis, photoperiod information is connected to FT through the CONSTANS gene $(C O)$, a zinc finger transcription activator expressed in leaves that activates the expression of $F T$ (Putterill et al., 1995; Kardailsky et al., 1999). The CONSTANS (CO) gene is posttranscriptionally regulated by GIGANTEA (GI), a circadian clock gene (Park et al., 1999; Huq et al., 2000). The FT protein moves to the shoot apical meristem (SAM) and activates the expression of floral determination genes to trigger flowering (Wigge et al., 2005; Corbesier et al., 2007). However, FT is tightly regulated in order to integrate other inputs, such as light quality or temperature, to ensure that flowering aligns with seasonal cues for successful reproduction (Valverde et al., 2004; Song et al., 2015). Additionally, vernalization and temperature are also important factors in regulating the expression of $F T$ in plants that require a period of cold before flowering such as the winter-annual ecotypes of Arabidopsis (Michaels and Amasino, 1999).

The flowering time pathways in other species share some similarities with Arabidopsis, but also have distinctive features (Zhu et al., 2017). In the short-day monocot Oryza sativa, Heading date $3 a$ (Hd3a) and FLOWERING LOCUS T 1 (RFT1) represent the orthologs of the Arabidopsis FT gene (Komiya et al., 2008). Heading date 1 (Hd1), the homolog of CO in rice, is regulated by OsGI (the GI homolog in rice) (Yano et al., 2000; Hayama et al., 2003). Hd1 promotes flowering by activating $H d 3 a$ expression under short-day conditions and delays flowering by repressing $\mathrm{Hd} 3 \mathrm{a}$ expression under long-day conditions (Yano et al., 2000; Kojima et al., 2002; Komiya et al., 2008). The Early heading date 1 (Ehd1) pathway, which is unique to grasses and independent of Hd1 (Doi et al., 2004), also promotes the expression of FLOWERING LOCUS T 1 (RFT1) and Hd3a (Doi et al., 2004, Xue et al., 2008, Itoh et al., 2010).

A very important domestication trait related to flowering time is the ability to flower at latitudes different from the plant's native region. Therefore, specific alleles of several important players in the flowering time pathway have been positively selected during domestication to achieve this.

Cultivated rice, O. sativa L., is a good example of a plant originally from a tropical region that has been adapted to a wide range of latitudes, from $53^{\circ} \mathrm{N}$ to $40^{\circ} \mathrm{S}$. The adaptation of rice to high latitudes was driven by the selection of natural variants of several genes from both $H d 1$ and Ehd1 pathways. Loss-of-function alleles of Hd1 itself (Goretti et al., 2017) or 
Table 1. Summary of the genes described in this article

\begin{tabular}{|c|c|c|c|c|}
\hline Gene ID & Arabidopsis homolog & Species & Molecular function & Pathway \\
\hline $\begin{array}{l}\text { HEADING DATE 3A (hd3A, } \\
\text { Os06t0157700) }\end{array}$ & FLOWERING LOCUS (FT, AT1G65480) & Oryza sativa & $\begin{array}{l}\text { Phosphatidylethanolamine } \\
\text { binding (GO:0008429) }\end{array}$ & Flowering time \\
\hline $\begin{array}{l}\text { RICE FLOWERING-LOCUS T } 1 \\
\text { (RFT1, Os06t0157500) }\end{array}$ & FLOWERING LOCUS (FT, AT1G65480) & Oryza sativa & $\begin{array}{l}\text { Phosphatidylethanolamine } \\
\text { binding (GO:0008429) }\end{array}$ & Flowering time \\
\hline $\begin{array}{l}\text { HEADING DATE } 7 \text { (Ghd7, } \\
\text { Os07g0261200) }\end{array}$ & NA & Oryza sativa & $\begin{array}{l}\text { DNA binding (GO:0003677), } \\
\text { protein binding (GO:000551) }\end{array}$ & Flowering time \\
\hline $\begin{array}{l}\text { Heading date (QTL)-5(t) (Hd5, } \\
\text { Os08g0174500) }\end{array}$ & NA & Oryza sativa & $\begin{array}{l}\text { DNA binding (GO:0003677), } \\
\text { protein binding (GO:0005515) }\end{array}$ & Flowering time \\
\hline Oryza sativa Pseudo-Response & Two-component response regulator-like (APRR7, & Oryza sativa & Protein binding (GO:0005515) & Flowering \\
\hline Regulator37 (OsPRR37, & AT5G02810) & & & Time \\
\hline Os07g0695100) & Pseudo-response regulator 3 (PRR3, AT5G60100) & & & \\
\hline $\begin{array}{l}\text { HEADING DATE } 1 \text { (Hd1, } \\
\text { Os06t0275000) }\end{array}$ & CONSTANS (CO, AT5G15840) & Oryza sativa & $\begin{array}{l}\text { Protein binding (GO:0005515), } \\
\text { zinc ion binding (GO:0008270) }\end{array}$ & Flowering time \\
\hline $\begin{array}{l}\text { Zea mays CCT transcription } \\
\text { factor } 9 \text { (ZmCCT9) }\end{array}$ & NA & $\begin{array}{l}\text { Zea mays ssp. } \\
\text { mays }\end{array}$ & $\begin{array}{l}\text { DNA binding (GO:0003677), } \\
\text { protein binding (GO:000551) }\end{array}$ & Photoperiod \\
\hline $\begin{array}{l}\text { Glycine max Cryptochrome } 1 \\
\text { (GmCRY1a, Glyma04G101500) }\end{array}$ & CRYPTOCROME 2 (CRY2, AT1G04400) & Glycine max & $\begin{array}{l}\text { Protein binding (GO:000551), } \\
\text { nucleotide binding } \\
\text { (GO:0000166) }\end{array}$ & Photoperiod \\
\hline $\begin{array}{l}\text { Glycine max CONSTANS-like } \\
7 a(\text { GMCOL7a) }\end{array}$ & CONSTANS (CO, AT5G15840) & Glycine max & $\begin{array}{l}\text { Protein binding (GO:0005515), } \\
\text { zinc ion binding (GO:0008270) }\end{array}$ & Flowering time \\
\hline GmGla (Glyma10g36600) & Protein G/GANTEA (AT1G22770) & Glycine max & Protein binding (GO:0005515) & Flowering time \\
\hline $\begin{array}{l}\text { Glycine max } \\
\text { phosphatidylethanolamine- } \\
\text { binding protein FT2a (GmFT2a, } \\
\text { Glyma16G150700) }\end{array}$ & FLOWERING LOCUS T (FT, AT1G65480) & Glycine max & $\begin{array}{l}\text { Phosphatidylethanolamine } \\
\text { binding (GO:0008429) }\end{array}$ & Flowering time \\
\hline $\begin{array}{l}\text { Helianthus annuus flowering } \\
\text { locus T4 (HaFT4, 110873663) }\end{array}$ & FLOWERING LOCUS T (FT, AT1G65480) & $\begin{array}{l}\text { Helianthus } \\
\text { annuus }\end{array}$ & $\begin{array}{l}\text { Phosphatidylethanolamine } \\
\text { binding (GO:0008429) }\end{array}$ & Flowering time \\
\hline Solyc09g075080 & $\begin{array}{l}\text { Phytochrome A-associated F-box protein (EID1, } \\
\text { AT4G02440) }\end{array}$ & $\begin{array}{l}\text { Solanum } \\
\text { lycopersicum }\end{array}$ & $\begin{array}{l}\text { Protein binding (GO:0005515), } \\
\text { ubiquitin-protein ligase activity } \\
\text { (GO:0004842) }\end{array}$ & Flowering time \\
\hline Solyc01g068560 & $\begin{array}{l}\text { NIGHT LIGHT-INDUCIBLE AND CLOCK- } \\
\text { REGULATED } 2 \text { (LNK2, AT3G54500) }\end{array}$ & $\begin{array}{l}\text { Solanum } \\
\text { lycopersicum }\end{array}$ & & Photoperiod \\
\hline $\begin{array}{l}\text { Teosinte branched } 1 \text { (tb1, } \\
\text { Zm00001d033673) }\end{array}$ & TEOSINTE BRANCHED 1 (TCP24, AT1G30210) & $\begin{array}{l}\text { Zea mays ssp. } \\
\text { mays }\end{array}$ & $\begin{array}{l}\text { DNA binding (GO:0003677), } \\
\text { DNA-binding transcription } \\
\text { factor activity (GO:0003700) }\end{array}$ & $\begin{array}{l}\text { Inflorescence } \\
\text { architecture }\end{array}$ \\
\hline $\begin{array}{l}\text { ABERRANT PANICLE ORGAN- } \\
\text { IZATION (Os06g0665400) }\end{array}$ & $\begin{array}{l}\text { Floral meristem identity control protein LEAFY (LFY, } \\
\text { AT5G61850) }\end{array}$ & Oryza sativa & $\begin{array}{l}\text { Ubiquitin-protein transferase } \\
\text { activity (GO:0004842), protein } \\
\text { binding (GO:0005515) }\end{array}$ & $\begin{array}{l}\text { Flower devel- } \\
\text { opment }\end{array}$ \\
\hline $\begin{array}{l}\text { Putative } \\
\text { phosphatidylethanolamine- } \\
\text { binding protein TFL1a } \\
\text { (GmTFL1, Glyma03G194700) }\end{array}$ & TERMINAL FLOWER 1 (TFL1, At5g03840) & Glycine max & $\begin{array}{l}\text { Transcription co-regulator ac- } \\
\text { tivity (GO:0003712) }\end{array}$ & $\begin{array}{l}\text { Flower devel- } \\
\text { opment }\end{array}$ \\
\hline $\begin{array}{l}\text { Self-pruning (sp, } \\
\text { Solyc06g074350) }\end{array}$ & CENTRORADIALIS (ATC, AT2G27550) & $\begin{array}{l}\text { Solanum } \\
\text { lycopersicum }\end{array}$ & $\begin{array}{l}\text { Phosphatidylethanolamine } \\
\text { binding (GO: 0008429) }\end{array}$ & $\begin{array}{l}\text { Flower devel- } \\
\text { opment }\end{array}$ \\
\hline $\begin{array}{l}\text { Brassica oleracea Transcription } \\
\text { factor CAULIFLOWER (BoCAL, } \\
\text { 106320120) }\end{array}$ & $\begin{array}{l}\text { Transcription factor CAULIFLOWER (CAL, } \\
\text { At1g26310) }\end{array}$ & $\begin{array}{l}\text { Brassica } \\
\text { oleracea }\end{array}$ & $\begin{array}{l}\text { Protein binding (GO:0005515), } \\
\text { DNA-binding transcription } \\
\text { factor activity (GO:0003700) }\end{array}$ & $\begin{array}{l}\text { Flower devel- } \\
\text { opment }\end{array}$ \\
\hline Falsiflora (fa, Solyc03g118160) & $\begin{array}{l}\text { Floral meristem identity control protein LEAFY (LFY, } \\
\text { AT5G61850) }\end{array}$ & $\begin{array}{l}\text { Solanum } \\
\text { lycopersicum }\end{array}$ & $\begin{array}{l}\text { Transcription factor binding } \\
\text { (GO:0008134) }\end{array}$ & $\begin{array}{l}\text { Flowering } \\
\text { time, flower } \\
\text { development }\end{array}$ \\
\hline $\begin{array}{l}\text { COMPOUND INFLORES- } \\
\text { CENCE (S, SolyC02g077390) }\end{array}$ & WUSCHEL HOMEOBOX 9 (WOX9, AT2G33880) & $\begin{array}{l}\text { Solanum } \\
\text { lycopersicum }\end{array}$ & DNA binding (GO:0003677) & $\begin{array}{l}\text { Inflorescence } \\
\text { architecture }\end{array}$ \\
\hline $\begin{array}{l}\text { LIGULELESS } 1 \text { (OsLG1, } \\
\text { Os04g0656500) }\end{array}$ & $\begin{array}{l}\text { Squamosa promoter-binding-like protein } 8 \text { (SPL8, } \\
\text { AT1G02065) }\end{array}$ & Oryza sativa & $\begin{array}{l}\text { DNA binding (GO:0003677), } \\
\text { metal ion binding } \\
(\mathrm{GO}: 0046872)\end{array}$ & $\begin{array}{l}\text { Flower devel- } \\
\text { opment }\end{array}$ \\
\hline CYCLOIDEA (CYC, O49250) & TEOSINTE BRANCHED 1 (TCP24, AT1G30210) & $\begin{array}{l}\text { Antirrhinum } \\
\text { majus }\end{array}$ & $\begin{array}{l}\text { DNA binding (GO:0003677), } \\
\text { DNA-binding transcription } \\
\text { factor activity (GO:0003700) }\end{array}$ & $\begin{array}{l}\text { Flower devel- } \\
\text { opment }\end{array}$ \\
\hline
\end{tabular}


3010 | Manrique et al.

Table 1. Continued

\begin{tabular}{|c|c|c|c|c|}
\hline Gene ID & Arabidopsis homolog & Species & Molecular function & Pathway \\
\hline DICHOTOMA (DICH, QOGFJ4) & NA & $\begin{array}{l}\text { Antirrhinum } \\
\text { majus }\end{array}$ & DNA binding (GO:0003677) & $\begin{array}{l}\text { Flower devel- } \\
\text { opment }\end{array}$ \\
\hline DIVARICATA (DIV, Q8S9H7) & NA & $\begin{array}{l}\text { Antirrhinum } \\
\text { majus }\end{array}$ & DNA binding (GO:0003677) & $\begin{array}{l}\text { Flower devel- } \\
\text { opment }\end{array}$ \\
\hline RADIALIS (RAD, Q58FS3) & NA & $\begin{array}{l}\text { Antirrhinum } \\
\text { majus }\end{array}$ & DNA binding (GO:0003677) & $\begin{array}{l}\text { Flower devel- } \\
\text { opment }\end{array}$ \\
\hline
\end{tabular}

the repressors of Ehd1, Grain number, plant height and heading date 7 (Ghd7) (Xue et al., 2008) and Days To Heading on chromosome 8 (DTH8/Ghd8/OsHAP3H/Hd5) (Xue et al., 2008; Wei et al., 2010; Fujino et al., 2013) were selected to obtain plants with low photoperiod sensitivity. Selection of natural variation of OsPRR37, a pseudo-response regulator (PRR) gene that makes up part of the circadian clock, also contributed to the adaptation of rice to cultivation at higher latitudes (Koo et al., 2013).

In maize, the adaptation to different geographical regions follows a similar pattern to that of rice. Maize (Zea mays ssp. mays) and its ancestor teosinte are native to tropical South-western Mexico. The adaptation of maize to higher latitudes is linked with the down-regulation of the gene ZmCCT9 (homolog of the rice gene Ghd7) by the insertion of a Harbinger-like transposon in a distant regulative region, which results in photoperiod insensitivity, allowing flowering in long-day conditions (Huang et al., 2018).

Conversely, the domestication of wheat and barley followed different trajectories. While some varieties were selected as winter crops, with day-neutral behaviour and a strong vernalization requirement, other varieties were selected as shortseasoned spring varieties not requiring vernalization (Blümel et al., 2015). However, in both cases, most known variations are associated with changes in VERNALIZATION 1 (VRN1), a MADS-box transcription factor gene involved in the vernalization process that promotes inflorescence initiation (Fjellheim et al., 2014).

In the case of soybean (Glycine max), adaptation to other latitudes is associated with a strong selection of the genes GmCRY1a (homolog of the Arabidopsis blue light receptor CRYPTOCROME 2) and GMCOL7a (homolog of CO) (Li et al., 2013). Soybean quantitative trait locus (QTL) analysis also linked four alleles (E1, E2, E3, and E4) to flowering time (Zhai et al., 2014). The major contributor, E2, is an allele of the GmGla gene, the soybean homeolog of GI of Arabidopsis. The dominant E2 allele carries an early stop codon mutation that leads to induction of the expression of the GmFT2a gene, producing early flowering (Langewisch et al., 2014). Another case in which FT is affected is sunflower (Helianthus annuus L.), where five members of the FT gene family were selected during domestication, including a non-functionalized copy (HaFT4) (Blackman et al., 2011).

Other interesting cases are the mutations selected in the tomato genes Solyc09g075080, the homolog of the Arabidopsis F-box EID1 that functions as a negative regulator in phytochrome A-specific light signaling, and Solyc01g068560, a homolog of the Arabidopsis NIGHT LIGHT-INDUCIBLE
AND CLOCK-REGULATED 2 (LNK2) that functions in the integration of light signaling and the circadian clock. They are responsible for the adaptation of this crop to the long summers in temperate regions. A single amino acid deletion in the Solyc09g075080/EID1 protein delays the circadian phase (Müller et al., 2016). For the Solyc01g068560/LNK2 gene, an almost complete deletion lengthens the circadian period (Müller et al., 2018).

\section{Modifications in inflorescence architecture during plant domestication}

The architecture of the inflorescence conditions the number of flowers and, as a consequence, fruits and seeds that are produced and their position on the plant (Wyatt, 1982; Evers et al., 2011; Iwata et al., 2012; Teo et al., 2014). Therefore, genes controlling inflorescence development are instrumental for domestication as they have a profound impact on key agronomical aspects such as yield and crop management (Benlloch et al., 2015).

Inflorescence architecture is determined by two main factors: the growth habit of the plant and the level of in/determinacy of the inflorescence meristem (IM). Regarding growth habit, in monopodial plants, such as Arabidopsis or rice, due to apical dominance, vertical growth results only from the SAM. In these plants, after floral transition, the main SAM develops into the leader inflorescence shoot with subordinate branches. Instead, in sympodial plants such as tomato, the role of the SAM is sequentially adopted by the uppermost axillary meristem, which, after a period of growth, will either terminate in reproductive structures or abort. Then, the growth will continue from a new axillary meristem that will repeat this pattern so, instead of a leader inflorescence, several inflorescences of similar size are formed along the shoot.

One of the best-known examples of genes modifying inflorescence architecture related to domestication is TEOSINTEBRANCHED 1 (TB1) of maize/teosinte. teosinte branched1 (tb1) was identified as a major QTL contributing to the shift towards monopodial growth habit with a concomitant increase in ear size during teosinte domestication (Doebley et al., 1997). tb1 encodes a member of the TCP family of transcriptional regulators expressed in the axillary meristems (Doebley et al., 1997; Hubbard et al., 2002; Kebrom and Brutnell, 2015). The TB1 protein acts as a repressor of organ growth and contributes to apical dominance by repressing branch outgrowth. The maize allele of TB1 is more highly expressed than that of teosinte, causing greater repression of branching compared with 
teosinte (Doebley et al., 1997; Studer et al., 2011). Increased expression of TB1 in maize is due to an insertion of a transposable element $65 \mathrm{~kb}$ upstream of the TB1 coding region (Studer et al., 2011; Kebrom and Brutnell, 2015).

The balance between the maintenance of indeterminacy or commitment to flower is the main determinant of the architecture of the inflorescence. Upon perception of inducing environmental and/or internal cues, the SAM transitions from a vegetative to a reproductive identity, becoming the primary IM (Wils and Kaufmann, 2017; Cheng et al., 2018). The primary IM $\left(\mathrm{I}_{1}\right)$ can either produce flowers or remain indeterminate to produce branch meristems $\left(\mathrm{I}_{2}\right)$, which iterate the pattern of $\mathrm{I}_{1}$ (Prusinkiewicz et al., 2007; Teo et al., 2014). Based on the activity of the $I_{1}$ and the $I_{2}$, inflorescences can be classified into four groups: when the $\mathrm{I}_{1}$ terminates as a flower, they are determinate inflorescences; in contrast, when the $\mathrm{I}_{1}$ grows indefinitely until senescence to produce a floral meristem (FM) or $\mathrm{I}_{2}$, they are indeterminate inflorescences. Additionally, when the $I_{2}$ forms the FM, we are in the presence of simple inflorescences. Alternatively, if the $\mathrm{I}_{2}$ forms further IMs, increasing the complexity of the architecture, we refer to them as compound inflorescences (Weberling, 1989; Benlloch et al., 2007, 2015; Cheng et al., 2018). A basic genetic model to explain how the balance between IM and FM identity is determined has been developed using studies in the model plant $A$. thaliana. Although the applicability of this model to other species is variable, it is useful to set a frame for comparison.

The development of the Arabidopsis inflorescence can be mostly explained by the function of three genes: TERMINAL FLOWER 1 (TFL1), LEAFY (LFY), and APETALA 1 (AP1) (Shannon and Meeks-Wagner, 1993; Liljegren et al., 1999; Blázquez et al., 2006; Benlloch et al., 2015). These genes coordinate to maintain the balance between IM and FM identity at the inflorescence apex. Broadly speaking, TFL1 promotes IM identity, while LFY and AP1 promote FM identity. Therefore, it has been proposed that differences in their expression patterns or function can explain much of the diversity of inflorescence architectures observed among angiosperms (Ratcliffe et al., 1999; Blázquez et al., 2006; Benlloch et al., 2007; SerranoMislata et al., 2017). Briefly, TFL1, a PEBP, is specifically expressed in the center of the $\mathrm{I}_{1}$ and $\mathrm{I}_{2}$, and promotes IM identity by repressing $L F Y$ and its direct target $A P 1$ (and its paralog CAULIFLOWER, CAL) to prevent early inflorescence termination (Mandel et al., 1992; Weigel et al., 1992; Weigel and Nilsson, 1995; Parcy et al., 1998; Teo et al., 2014). Conversely, $L F Y$, a plant-specific transcription factor gene, and $A P 1$ and $C A L$, two paralog MADS-box transcription factor genes, are expressed in the lateral FM primordia produced by the IM.The joint action of LFY and AP1/CAL in the newly formed FM leads to the repression of TFL1, allowing the up-regulation of floral organ identity genes and leading to the formation of flowers (Parcy et al., 1998; Liljegren et al., 1999; Wagner et al., 1999; Kaufmann et al., 2009). However, the mechanism leading to TFL1 repression in the FM is not linear. Recent works pointed out that, actually, LFY activates TFL1 in the FM while AP1/CAL represses it (Goslin et al., 2017; SerranoMislata et al., 2017). This indicates that LFY and AP1 might be part of a feed-forward loop that could serve to ensure that flower development starts only when AP1/CAL levels are high enough to over-ride LFY inhibitory action, ensuring that the conditions for stable development of flowers are already established (Goslin et al., 2017). These results imply that LFY might also be involved in maintaining the indeterminate growth of the IM. Indeed, the activity of the TFL1 promoter is reduced in Ify mutants (Serrano-Mislata et al., 2017). Although LFY is not expressed in the SAM, LFY protein is mobile (Sessions et al., 2000) so it can travel to the IM and bind to the TFL1 promoter. Therefore, the relationship between TFL1 and LFY is not entirely antagonistic as previously thought.

Regarding the situation in other plants, of the three genes forming the model, TFL1 is the most conserved. TFL1 orthologs exist in most land plants, and investigations in various plant species have shown that their role is mostly conserved (Chardon and Damerval, 2005; Carmona et al., 2007; Danilevskaya et al., 2010; C. Liu et al., 2013; Teo et al., 2014; Mahrez et al., 2016). Mutations of TFL1 produce a switch to more determinate inflorescences. Examples of crops where this has been selected during domestication are soybean and tomato (Wang et al., 2018). Glycine soja, the wild progenitor of soybean (G. max), is indeterminate. Instead, many cultivated soya varieties have a determinate growth habit. This trait was found to be controlled by the Dt 1 locus encoded by GmTFL1 (Liu et al., 2010). As soybean contains several TFL1 paralogs, complementation of the Arabidopsis tff1 mutant with GmTFL1 demonstrated that it was the functional TFL1 ortholog (Tian et al., 2010).

Instead, the presence and role of LFY and $A P 1$ vary among species. For example, the rice ortholog of $L F Y, A B E R R A N T$ PANICLE ORGANIZATION 2/RICE FLORICAULA, is not expressed in FMs and, in contrast to Arabidopsis, it has a role in suppressing the transition from IM to FM (Kyozuka et al., 1998; Ikeda-Kawakatsu et al., 2012).

Another example is the tomato self-pruning ( $s p$ ) mutant. $s p$ was discovered 90 years ago and has facilitated the transformation of indeterminate tomato plants into new determinate forms (Yeager, 1927; Pnueli et al., 1998; Wang et al., 2018), leading to a more compact phenotype and synchronized growth which is adequate for mechanical harvesting (McGarry et al., 2016). For this reason, the SP mutation was rapidly bred into all industrial tomatoes. However, it must be noted that although the product of $S P$ is a PEBP and the functional equivalent of that of TFL1 in tomato, the real ortholog of $S P$ in Arabidopsis is another PEBP-encoding gene, Arabidopsis thaliana CENTRORADIALIS (ATC) (Mimida et al., 2001; McGarry et al., 2016).

Obvious examples of inflorescence architecture re-shaping associated with domestication are the mutants of Brassica oleracea, cauliflower (B. oleracea ssp. botrytis), and broccoli (B. oleracea ssp. Italica). The cauliflower head is composed of a hypertrophied mass of IMs and FMs. In broccoli, developmental arrest happens at a later stage, so although the inflorescence also develops into a large hypertrophied structure, flower buds are eventually formed (Carr and Irish, 1997; Schilling et al., 2018). Upon the characterization of the ap 1-1/cal-1 mutant of Arabidopsis, the similarity of broccoli and cauliflower with it led to speculation that the AP1 and CAL orthologs 
from B. oleracea might be responsible for this phenotype (Smith and King, 2000). Surprisingly, the link is not as clear as initially thought and, at present, the basis of these phenotypes is still not completely clear. Molecular and population genetic studies indicate that the function of the $B$. oleracea $C A L(B o C A L)$ is compromised in both varieties (Kempin et al., 1995; Lowman and Purugganan, 1999; Purugganan et al., 2000; Smith and King, 2000). The situation for $A P 1$-like genes is less clear, since several copies of AP1-like genes exist in B. oleracea (Lowman and Purugganan, 1999) and, although they are associated with the phenotype, they do not explain it entirely, indicating that additional genes might be involved (Labate et al., 2006; Duclos and Björkman, 2008; Schilling et al., 2018).

Besides TFL1, LFY, and AP1, many other genes involved in the network that regulates inflorescence architecture have been targeted during domestication. For example, although mutations in FALSIFLORA (FA), the ortholog of $L F Y$ in tomato, cause an increase in inflorescence branching (Molinero-Rosales et al., 1999; Zheng et al., 2017), most commercial highly branched tomato varieties carry mutations on COMPOUND INFLORESCENCE (S). S encodes a homolog of WUSCHEL HOMEOBOX 9 (WOX9) of Arabidopsis. WOX9 in Arabidopsis is involved in SAM and root apical meristem (RAM) maintenance (Wu et al., 2005, 2007) and embryo patterning (Haecker et al., 2004; Wu et al., 2007; Ueda et al., 2011), and has no effect on inflorescence branching in Arabidopsis, a difference probably originating from the different growth habits (Lippman et al., 2008). Another example is the mutation on the regulatory regions of OsLG1 or OsSPL8, encoding a squamosa promoter-binding-like protein which is responsible for the switch from a spread panicle in wild rice to the compact panicle of domesticated rice (Zhu et al., 2013).

\section{Floral crop selection as an example of alterations in flower development pathways}

Perfect flowers contain four types of organs arranged in concentric rings known as whorls. From the outermost to innermost whorl, the organ types are: sepals, petals, stamens, and carpels. A combinatorial model that explains how these four organ types are specified within the FM was proposed in the early 1990s, based on the observation of a series of homeotic mutants in Arabidopsis and Antirrhinum (Causier et al., 2010; Moyroud and Glover, 2017). Presently known as the ABCDE model, the model was originally proposed as the ABC model and extended later on (Coen and Meyerowitz, 1991; Weigel and Meyerowitz, 1994; Causier et al., 2010).

The model proposes that five functions named A, B, C, D, and $\mathrm{E}$ specify which organs form in each whorl of the flower. $\mathrm{A}+\mathrm{E}$ genes specify sepals, $\mathrm{A}+\mathrm{B}+\mathrm{E}$ specify petals, $\mathrm{B}+\mathrm{C}+\mathrm{E}$ specify stamens, $\mathrm{C}+\mathrm{E}$ specify carpels, and $\mathrm{C}+\mathrm{D}+\mathrm{E}$ specify ovules, and the ABCDE genes are sufficient to superimpose floral organ identity in vegetative organs of angiosperms (Parcy et al., 1998; Honma and Goto, 2001; Pelaz et al., 2001).Additionally, it was observed that $\mathrm{C}$-function expands into the outer whorls in A-function mutants and vice versa,so mutual repression between the A- and C-functions was integrated into the model to explain it (Causier et al., 2010). In Arabidopsis, the genes responsible for A-function are APETALA1 (AP1) and APETALA2 (AP2), B-function is encoded by APETALA3 (AP3) and PISTILLATA (PI), and C-function is encoded by AGAMOUS (AG) (Yanofsky et al., 1990; Jack et al., 1992; Mandel et al., 1992; Goto and Meyerowitz, 1994; Jofuku et al., 1994; Theißen et al., 2016). Three paralog MADS-box genes are responsible for the D-function: SEEDSTICK (STK), SHATTERPROOF1 (SHP1), and SHATTERPROOF2 (SHP2) (Favaro et al., 2003; Pinyopich et al., 2003), and E-function is redundantly encoded by SEPALLATA genes (SEP1-SEP4) (Pelaz et al., 2000, 2001; Ditta et al., 2004). Except for AP2, which is an AP2/EREBP (ethylene-responsive element-binding protein), all the other ABCDE genes encode MIKC-type MADS-box transcription factors. MADS-domain proteins can interact with each other, forming tetramers, explaining the combinatorial nature of the model: each organ is determined by a specific tetrameric combination of floral identity MADS-box proteins (Theißen and Saedler, 2001; Theißen et al., 2016). This is known as the floral quartet model (Stewart et al., 2016).

Although the model is 30 years old, the conceptual framework continues to be broadly valid. Floral identity genes are also present in gymnosperms, where a 'BC' model has been proposed (Baum and Hileman, 2006; Theissen and Melzer, 2007; Chanderbali et al., 2016), in which C-function is expressed in male and female cones while $\mathrm{B}$-function is restricted to male cones (Irish, 2017). In this context, the ABCDE model can be seen as an evolutionary extension of the 'BC' model. Instead, A-function has always been controversial as it seems to be much less conserved than the others and, in the last years, evidence has been accumulating pointing to the fact that outside Arabidopsis and close relatives, a classical A-function is rare (Litt, 2007; Ye et al., 2016; Morel et al., 2017; Wils and Kaufmann, 2017; Schilling et al., 2018). However, a recent study has shown that, in rice, A-function exists and it is performed by OsMADS14 and OsMADS15 genes which belong to the AP1/FUL clade (Wu et al., 2017), so the debate is still open.

The other functions are quite well conserved across angiosperms, particularly eudicots and monocots, although, for example, in petunia C- and D-function cannot be strictly distinguished from each other (Heijmans et al., 2012; Theißen et al., 2016; Schilling et al., 2018). Finally, some differences that do not fit in a whorl-based ABCDE model are observed in some basal angiosperms. However, those differences can be explained as modifications of the ABCDE model like the 'fading borders model' (Causier et al., 2010; Chanderbali et al., 2016; Wils and Kaufmann, 2017).

Regarding modification of flower morphology due to domestication, probably the most frequent and notorious examples are the alterations in $A G$ that result in double flowers where stamens and carpels are replaced by petals (Bowman et al., 1989; Schilling et al., 2018). Since the determinacy of the meristem is also disturbed, this pattern is iterated multiple times, leading to flowers with very high numbers of petals (Bowman et al., 1989). In some cases, double flowers are associated with loss-of-function mutations in $A G$-like genes, such as, for example, in rue-anemone (Thalictrum thalictroides) or 
Japanese cherry (Prunus lannesiana) (Galimba et al., 2012; Z. Liu et al., 2013; Schilling et al., 2018). However, the formation of double flowers in rose, Camellia, or lily is instead associated with a restriction of the expression domain of $A G$-like genes toward the center of the meristem (Dubois et al., 2010; Akita et al., 2011; Sun et al., 2014). The underlying molecular cause of the shrinkage of the $A G$ expression domain was unknow,n but recent data from rose and peach indicate that it might be caused by mutations in euAP2 genes, which are known to repress $A G$ in many species (François et al., 2018; Gattolin et al., 2018). It seems that in both cases the mutations responsible for the change in the AG expression pattern were caused by the loss of the miR172-binding site in the euAP2 gene (François et al., 2018; Gattolin et al., 2018).

Besides floral organs, the symmetry of flowers is a characteristic often modified during domestication, especially in ornamental crops. Flowers can have two types of symmetry: radial or actinomorphy and bilateral or zygomorphy (Endress, 1999; Krizek and Fletcher, 2005; Smyth, 2018). Zygomorphy is thought to have evolved many times from an ancestral actinomorphic condition as a strategy apparently associated with the attraction of pollinating insects with bilateral vision (Krizek and Fletcher, 2005; Smyth, 2018). Although the classification is binary, the outcome is not, as differential development of each whorl can give rise to several intermediate situations. For example, while orchids are the classical example of zygomorphy and show a strong bilateral symmetry spanning all whorls, some species of Solanum present a restricted zygomorphy affecting only the stamen whorl, related to their interaction with pollen-collecting bees (Glover et al., 2004).

Snapdragon (A. majus) is the classic genetic model in which zygomorphy has been studied. Its symmetry is based on the expansion of the dorsal petals relative to the lateral and ventral ones and abortion of the dorsal stamen (Krizek and Fletcher, 2005). Dorsal identity is specified by two paralogous TCPdomain family transcription factor genes with overlapping functions, CYCLOIDEA (CYC) and DICHOTOMA (DICH). Ventral identity is specified by the MYB-domain transcription factor gene DIVARICATA (DIV), expressed all across the flower. Expression of $C Y C$ and $D I C H$ in the dorsal domain activates RADIALIS (RAD), which encodes a protein with a single MYB domain. RAD antagonizes DIV function in dorsal cells and limits its activity to the lateral and ventral domains by competing for DIV interaction partners, the DIV-ANDRAD-INTERACTING-FACTORS (DRIFs), which are required for DIV activity in specifying ventral symmetry (Luo et al., 1996, 1999; Galego and Almeida, 2002; Corley et al., 2005; Perez-Rodriguez et al., 2005; Gao et al., 2017). Thus, rad and cyc dich double mutants are ventralized and have a radially symmetrical appearance. Many regressions to actinomorphic symmetry, both in natural populations (Cubas et al., 1999; Reardon et al., 2009) and in domesticated crops, are caused by mutations affecting CYC expression. A recent example of zygomorphic to actinomorphic reversion in a domesticated plant caused by a mutation in a CYC ortholog are gloxinias (Sinningia speciosa), where the loss of CYC function is caused by a $10 \mathrm{bp}$ deletion in the coding sequence of the gene (Dong et al., 2018).
CYC-like genes have also been associated with asymmetric pigmentation in zygomorphic flowers. For example, TfCYC2 in wishbone flower (Torenia fournieri) evolved regulatory loops to bind to the promoter region of an R2R3-MYB factor gene repressing its transcription, which under normal circumstances promotes anthocyanin-related pigmentation in the epidermal cells of petals (Su et al., 2017).

\section{Limitations in plant breeding driven by pre- fertilization self-incompatibility}

Plant fitness/yield has been fundamentally changed during domestication by hybridization, genetic bottlenecks, alteration of reproductive strategies, and polyploidization. Such changes have greatly modulated current plant traits in agriculture. Angiosperms exhibit a wide array of reproductive strategies, both asexual and sexual, with sexual reproduction including self-fertilization and cross-fertilization strategies. In unstable or unpredictable environments, reproductive strategies promoting cross-fertilization are fundamental to evolutionary success as they contribute to the creation of genetically diverse populations which increase the probability that at least one individual in a population will survive under changing conditions. However, in situations of low presence of sexual partners, or in stable and predictable environments, an asexual strategy and self-fertilization are effective means of reproduction that can be favored. Numerous wild plants display efficient mechanisms that ensure outcrossing promoting high levels of plant heterozygosity. SI is reported in $>100$ families and distributed among an estimated 39\% of species (Igic and Kohn, 2006). During angiosperm evolution, different molecular mechanisms for promoting SI have evolved at least 35 times (Iwano and Takayama, 2012). Self-compatibility (SC), on the other hand, might have evolved to adapt to conditions such as the loss of pollinators (Gervasi and Schiestl, 2017).

Perennial species are generally outcrossers, while annuals are more tolerant to SC. Since annuals only have one chance to reproduce during their lifespan, for them it might be better to self-pollinate, rather than not reproducing at all. Conversely, perennial species can wait longer and avoid the detrimental effects of inbreeding over time (Pekkala et al., 2014).

Outcrossing can be achieved either through the spatiotemporal separation of the sexes via (hetero) dichogamy or dioecy, or by SI (Miller and Gross, 2011). SI is a genetically controlled mechanism that induces a higher sexual selection by preventing self-fertilization in wild-type plants. In some cases, SI arises from floral morphology (heteromorphology) thanks to genetically controlled physical or temporal barriers that prevent self-pollination. This is the case for primrose (Primula) which exhibits two floral forms (morphs) that differ in morphology, primarily in the relative placement of stigmas and anthers, and pollinations succeed only between different morphs (De Nettancourt, 2001). Multiple varieties of heteromorphic SI systems are present in the plant kingdom (seen in Passifloraceae, Lythraceae, Polygonaceae, and Primulaceae) which are considered to have evolved independently (Fujii et al., 2016). 
Nevertheless, most SI systems in plants belong to homomorphic systems where incompatibility is achieved by one-to-one interaction of two or a few genes. SI was originally classified into two types: (i) gametophytic SI (GSI) and (ii) sporophytic SI (SSI), based on the genetic control of the SI phenotype by pollen. A late-acting SI system (LSI) has been also described in several species recently (see review by Gibbs, 2014).

GSI has been described in Rosaceae, Plantaginacea, Papaveraceae, and Solanaceae. According to the phylogeny and the conserved structure of the female S-RNase gene, it seems that this gene evolved only once, before the separation of the Asterideae and Rosideae, 120 million years ago (Vieira et al., 2009). GSI has a common molecular basis across many plant families and is probably the ancestral condition for flowering plants (McClure, 2006). In contrast, SSI is present in at least 10 plant families and derives from at least 17 distinct evolutionary origins (Igic et al., 2008; Koseva et al., 2017). In SSI, S-specificity is determined by the genotype of the sporophyte that produced the pollen grain (Sehgal and Singh, 2018). SSI has been most deeply characterized in Brassicaceae (Hiscock and Tabah, 2003; Kitashiba and Nasrallah, 2014; Lao et al., 2014; Iwano et al., 2015; Baldwin and Schoen, 2017). More recently, substantial advances have been made in describing SSI in Asteraceae (Gonthier et al., 2013; Koseva et al., 2017).

Finally, in LSI, both compatible and incompatible pollen grains can reach the ovary with a similar rate of pollen tube growth. However, whilst the double fertilization is completed after $24 \mathrm{~h}$ in compatible reactions, in incompatible reactions the male nuclei are released into the embryo sac, but they fail to achieve gamete fusion, resulting in floral abscission. LSI cases range from Malvaceae, Apocynaceae, and Bignoniaceae, to the monocot families Amaryllidaceae and Xanthorroeaceae (Gibbs, 2014).A well-characterized LSI case is Theobroma cacao (da Silva et al., 2016; Lanaud et al., 2017). Most of the T. cacao accessions are self incompatible; however, some anciently domesticated varieties, such as 'Criollo' varieties from Central America originally cultivated by the Mayas, or 'Comun' from Brazil and 'Nacional' from Ecuador, are self-compatible (Loor Solorzano et al., 2012; Santos et al., 2015).

During domestication, SI has been introduced, or removed, according to agronomic parameters of interest (McClure, 2012). For example, in some fruit trees of the Rosaceae family, such as apple, Japanese pear, sweet cherry, or apricot, trees of different cross-compatible varieties should be planted to ensure fruit production due to SI (Sassa, 2016). Similar situations have been reported for other crops such as cabbage, chicory, or sugar beet (Ockendon, 1974; Broothaerts, 2003; Wünsch and Hormaza, 2004; Hunt et al., 2010; Gonthier et al., 2013; Sassa, 2016; Saumitou-Laprade et al., 2017; Farinelli et al., 2018). An interesting example is the genus Prunus, a large genus in the Rosaceae family, that includes multiple domesticated crops such as almond, apricot, cherry, peach, and plum. Most of the Prunus species exhibit S-RNase-based gametophytic SI. In some species such as almond, domestication goals were exclusively focused on improving organoleptic aspects such as reduced toxicity, thinner endocarp, and increased seed size. In contrast, in other cases, such as peach, domestication was focused not only on improving aspects affecting fruit morphology but also on the introduction of SC (Miller and Gross, 2011). Other crops of the genus Prunus such as cherries and plums also have had SC introduced during their domestication (Spiegel-Roy, 1986). Modern breeding programs oriented towards disrupting SI in almond only began recently (MartínezGómez et al., 2006).

Other perennial species have evolved SC under domestication. For instance, wild grapevine is dioecious while the domesticated relative is hermaphrodite and self-compatible (De Mattia et al., 2008). In contrast to perennials where few crops derive from selfing wild populations, many annual crops have been domesticated from SC wild ancestors, such as barley, chickpea, eggplant, lentils, pea, chile, tomatoes, and wheat (Miller and Gross, 2011).

However, SI can also be a desirable trait for breeders. SI systems prevent self-fertilization, which forces outcrossing and increases genetic diversity, which is useful for the breeding of hybrid varieties of economically important plant families. Accordingly, breeding programs towards introducing functional SI have been activated in many crops (KaothienNakayama et al., 2010; Havlícková et al., 2014; Cheng et al., 2018; Xiao et al., 2019). In order to control mating, many advances have been made toward understanding the SI mechanisms. However, transferring these mechanisms across wide phylogenetic distances is often difficult, or even impossible, for breeders. Recently, de Graaf and co-workers introduced an SI system (from Papaver) in a species with no SI system that diverged $\sim 140$ million years ago (de Graaf et al., 2012), demonstrating that this transfer may be easier than previously thought.

Asexually (clonally) propagated crops where sexual reproduction is reduced have also been promoted by breeders. Vegetative propagation might be preferred to sexual reproduction either to avoid the segregation of traits in SI species (McKey et al., 2010) or to speed up breeding and growing cycles in perennials with long juvenile phases. For this reason, many tree crops such as avocado or olive trees are propagated clonally (Diez et al., 2015; Kuhn et al., 2019).

An interesting example of a herbaceous plant that is clonally propagated is banana. The banana domestication involved hybridizations between diverse species and subspecies that generated diploid and triploid sterile hybrids. Nonetheless, the hybrids are able to produce parthenocarpic fruits that have been thereafter dispersed by vegetative propagation (D'Hont et al., 2012).

Clonally propagated crops can potentially produce a wider range of adaptations with respect to sexual reproductive families that are easily maintained, but genetic homogeneity is an important drawback for survival if adverse conditions arise. For example, half of the 2018 banana world production relies on somaclones derived from a single triploid genotype (Cavendish) (Lescot, 2010). Since pests and diseases have gradually become adapted, at present this genetic homogeneity represents an imminent danger for global banana production (de Bellaire et al., 2010; Dita et al., 2010). 


\section{Final remarks}

Many of the changes selected during domestication are related to reproductive traits, either because the outcome of the reproductive process (seeds or fruits) is the desired result, or because the alteration of the reproductive process is necessary to achieve it (i.e. to be able to cross varieties/ species or to avoid undesirable phenotype variation). In this review, we have summarized some of the changes associated with molecular mechanisms that human action have introduced into the reproductive structures and strategies of domesticated plants. Darwin already noticed many of the changes in reproductive structures and strategies introduced by domestication, but he lacked the tools to understand their basis. At present, many domestication-driven changes in plant reproduction are still not well understood because crop molecular biology research has developed more slowly than that based on model plants. Recently developed tools such as genome editing and next-generation sequencing are changing this scenario and quickly increasing our knowledge of the molecular basis of domestication in crop species. This will also allow for better planning of breeding strategies in the future.

\section{Acknowledgements}

We would like to acknowledge the FruitLook FP7-PEOPLE-2013IRSES-Marie Curie Action (Project ID: 612640), the SexSeed H2020-EU.1.3.3. MSCA-RISE-Marie Skłodowska-Curie Research, Innovation Staff Exchange project (Project ID: 690946), H2020-MSCA RISE Project (ExpoSeed GA-691109), and the Università degli Studi di Milano (UNIMI-RTD and Linea 2-DBS) for bringing together the team that developed this article. PG is grateful to Universitat Politècnica de València (PAID-10-18) and to the Japan Society for the Promotion of Science [FY2019 JSPS Postdoctoral Fellowship for Research in Japan (Standard)] for their respective postdoctoral grants. We would also like to thank the Society of Experimental Biology for the opportunity of summarizing some of our ideas in this article.

\section{References}

Akita Y, Nakada M, Kanno A. 2011. Effect of the expression level of an AGAMOUS-like gene on the petaloidy of stamens in the double-flowered lily, 'Elodie'. Scientia Horticulturae 128, 48-53.

Baldwin SJ, Schoen DJ. 2017. Genetic variation for pseudo-selfcompatibility in self-incompatible populations of Leavenworthia alabamica (Brassicaceae). New Phytologist 213, 430-439.

Baum DA, Hileman LC. 2006. A developmental genetic model for the origin of the flower. In: Ainsworth C, ed. Flowering and its manipulation. Oxford: Blackwell Publishing Ltd, 1-27.

Benlloch R, Berbel A, Ali L, Gohari G, Millán T, Madueño F. 2015. Genetic control of inflorescence architecture in legumes. Frontiers in Plant Science 6, 543.

Benlloch R, Berbel A, Serrano-Mislata A, Madueño F. 2007. Floral initiation and inflorescence architecture: a comparative view. Annals of Botany 100, 659-676.

Blackman BK, Rasmussen DA, Strasburg JL, Raduski AR, Burke JM, Knapp SJ, Michaels SD, Rieseberg LH. 2011. Contributions of flowering time genes to sunflower domestication and improvement. Genetics 187, $271-287$.
Blázquez MA, Ferrándiz C, Madueño F, Parcy F. 2006. How floral meristems are built. Plant Molecular Biology 60, 855-870.

Blümel M, Dally N, Jung C. 2015. Flowering time regulation in cropswhat did we learn from Arabidopsis? Current Opinion in Biotechnology $\mathbf{3 2}$, 121-129.

Bowman JL, Smyth DR, Meyerowitz EM. 1989. Genes directing flower development in Arabidopsis. The Plant Cell 1, 37-52.

Broothaerts W. 2003. New findings in apple S-genotype analysis resolve previous confusion and request the re-numbering of some S-alleles. Theoretical and Applied Genetics 106, 703-714.

Carmona MJ, Calonje M, Martínez-Zapater JM. 2007. The FT/TFL1 gene family in grapevine. Plant Molecular Biology 63, 637-650.

Carr SM, Irish VF. 1997. Floral homeotic gene expression defines developmental arrest stages in Brassica oleracea L. vars. botrytis and italica. Planta 201, 179-188.

Causier B, Schwarz-Sommer Z, Davies B. 2010. Floral organ identity: 20 years of ABCs. Seminars in Cell \& Developmental Biology 21, 73-79.

Chanderbali AS, Berger BA, Howarth DG, Soltis PS, Soltis DE. 2016. Evolving ideas on the origin and evolution of flowers: new perspectives in the genomic era. Genetics 202, 1255-1265.

Chardon F, Damerval C. 2005. Phylogenomic analysis of the PEBP gene family in cereals. Journal of Molecular Evolution 61, 579-590.

Cheng X, Li G, Tang Y, Wen J. 2018. Dissection of genetic regulation of compound inflorescence development in Medicago truncatula. Development 145, dev158766.

Coen ES, Meyerowitz EM. 1991. The war of the whorls: genetic interactions controlling flower development. Nature 353, 31-37.

Corbesier L, Vincent C, Jang S, et al. 2007. FT protein movement contributes to long-distance signaling in floral induction of Arabidopsis. Science 316, 1030-1033.

Corley SB, Carpenter R, Copsey L, Coen E. 2005. Floral asymmetry involves an interplay between TCP and MYB transcription factors in Antirrhinum. Proceedings of the National Academy of Sciences, USA 102, 5068-5073.

Cubas P, Vincent C, Coen E. 1999. An epigenetic mutation responsible for natural variation in floral symmetry. Nature 401, 157-161.

Danilevskaya ON, Meng X, Ananiev EV. 2010. Concerted modification of flowering time and inflorescence architecture by ectopic expression of TFL1-like genes in maize. Plant Physiology 153, 238-251.

Darwin C. 1859. On the origin of species. London: Routledge.

Darwin C. 1868. The variation of animals and plants under domestication. London: John Murray.

da Silva MR, Clément D, Gramacho KP, Monteiro WR, Argout X, Lanaud C, Lopes U. 2016. Genome-wide association mapping of sexual incompatibility genes in cacao (Theobroma cacao L). Tree Genetics \& Genomes 12, 62.

de Bellaire LDL, Fouré E, Abadie C, Carlier J. 2010. Black leaf streak disease is challenging the banana industry. Fruits 65, 327-342.

de Graaf BH, Vatovec S, Juárez-Díaz JA, Chai L, Kooblall K, Wilkins KA, Zou H, Forbes T, Franklin FC, Franklin-Tong VE. 2012. The Papaver self-incompatibility pollen S-determinant, PrpS, functions in Arabidopsis thaliana. Current Biology 22, 154-159.

De Mattia F, Imazio S, Grassi F, Baneh HD, Scienza A, Labra M. 2008. Study of genetic relationships between wild and domesticated grapevine distributed from Middle East Regions to European countries. Rendiconti Lincei Scienze Fisiche e Naturali 19, 223-240.

De Nettancourt D. 2001. Incompatibility and incongruity in wild and cultivated plants. Berlin: Springer Science \& Business Media.

DeVries H. 1904. Species and varieties: their origin by mutation. Chicago, IL: Open Court Publishing Company.

D'Hont A, Denoeud F, Aury JM, et al. 2012. The banana (Musa acuminata) genome and the evolution of monocotyledonous plants. Nature 488, 213-217.

Diez CM, Trujillo I, Martinez-Urdiroz N, Barranco D, Rallo L, Marfil P, Gaut BS. 2015. Olive domestication and diversification in the Mediterranean Basin. New Phytologist 206, 436-447. 
Dita MA, Waalwijk C, Buddenhagen IW, Souza Jr MT, Kema GHJ. 2010. A molecular diagnostic for tropical race 4 of the banana fusarium wilt pathogen. Plant Pathology 59, 348-357.

Ditta G, Pinyopich A, Robles P, Pelaz S, Yanofsky MF. 2004. The SEP4 gene of Arabidopsis thaliana functions in floral organ and meristem identity. Current Biology 14, 1935-1940.

Doebley J, Stec A, Hubbard L. 1997. The evolution of apical dominance in maize. Nature 386, 485-488.

Doi K, Izawa T, Fuse T, Yamanouchi U, Kubo T, Shimatani Z, Yano M, Yoshimura A. 2004. Ehd1, a B-type response regulator in rice, confers short-day promotion of flowering and controls $F T$-like gene expression independently of Hd1. Genes \& Development 18, 926-936.

Dong Y, Liu J, Li PW, Li CQ, Lü TF, Yang X, Wang YZ. 2018. Evolution of Darwin's peloric gloxinia (Sinningia speciosa) is caused by a null mutation in a pleiotropic TCP gene. Molecular Biology and Evolution 35, 1901-1915.

Dubois A, Raymond O, Maene M, Baudino S, Langlade NB, Boltz V, Vergne P, Bendahmane M. 2010. Tinkering with the C-function: a molecular frame for the selection of double flowers in cultivated roses. PLoS One 5, e9288.

Duclos DV, Björkman T. 2008. Meristem identity gene expression during curd proliferation and flower initiation in Brassica oleracea. Journal of Experimental Botany 59, 421-433.

Endress PK. 1999. Symmetry in flowers: diversity and evolution. International Journal of Plant Sciences 160, S3-S23.

Evers JB, van der Krol AR, Vos J, Struik PC. 2011. Understanding shoot branching by modelling form and function. Trends in Plant Science 16, 464-467.

Farinelli D, Breton C, Koubouris G, Famiani F, Villemur P, Bervillé A. 2018. Reply to Saumitou-Laprade et al. (2017). Controlling for genetic identity of varieties, pollen contamination and stigma receptivity is essential to characterize the self-incompatibility system of Olea europaea L. Evolutionary Applications 11, 1465-1470.

Favaro R, Pinyopich A, Battaglia R, Kooiker M, Borghi L, Ditta G, Yanofsky MF, Kater MM, Colombo L. 2003. MADS-box protein complexes control carpel and ovule development in Arabidopsis. The Plant Cell 15, 2603-2611.

Fjellheim S, Boden S, Trevaskis B. 2014. The role of seasonal flowering responses in adaptation of grasses to temperate climates. Frontiers in Plant Science 5, 431.

François L, Verdenaud M, Fu X, Ruleman D, Dubois A, Vandenbussche $M$, Bendahmane $A$, Raymond 0 , Just $J$ Bendahmane M. 2018. A miR172 target-deficient AP2-like gene correlates with the double flower phenotype in roses. Scientific Reports 8, 12912.

Fujii S, Kubo K, Takayama S. 2016. Non-self- and self-recognition models in plant self-incompatibility. Nature Plants 2, 16130.

Fujino K, Yamanouchi U, Yano M. 2013. Roles of the Hd5 gene controlling heading date for adaptation to the northern limits of rice cultivation. Theoretical and Applied Genetics 126, 611-618.

Galego L, Almeida J. 2002. Role of DIVARICATA in the control of dorsoventral asymmetry in Antirrhinum flowers. Genes \& Development 16, 880-891.

Galimba KD, Tolkin TR, Sullivan AM, Melzer R, Theißen G, Di Stilio VS. 2012. Loss of deeply conserved C-class floral homeotic gene function and C- and E-class protein interaction in a double-flowered ranunculid mutant. Proceedings of the National Academy of Sciences, USA 109, E2267-E2275.

Gao A, Zhang J, Zhang W. 2017. Evolution of $R A D$ - and $D I V$-like genes in plants. International Journal of Molecular Sciences 18, 1961.

Gattolin S, Cirilli M, Pacheco I, et al. 2018. Deletion of the miR172 target site in a TOE-type gene is a strong candidate variant for dominant doubleflower trait in Rosaceae. The Plant Journal 96, 358-371.

Gervasi DD, Schiestl FP. 2017. Real-time divergent evolution in plants driven by pollinators. Nature Communications 8, 14691.

Gibbs PE. 2014. Late-acting self-incompatibility-the pariah breeding system in flowering plants. New Phytologist 203, 717-734.

Glover BJ, Bunnewell S, Martin C. 2004. Convergent evolution within the genus Solanum: the specialised anther cone develops through alternative pathways. Gene 331, 1-7.

Gonthier L, Blassiau C, Mörchen M, Cadalen T, Poiret M, Hendriks T, Quillet MC. 2013. High-density genetic maps for loci involved in nuclear male sterility (NMS1) and sporophytic self-incompatibility (S-locus) in chicory (Cichorium intybus L., Asteraceae). Theoretical and Applied Genetics 126, 2103-2121.

Goretti D, Martignago D, Landini M, et al. 2017. Transcriptional and post-transcriptional mechanisms limit heading date 1 (Hd1) function to adapt rice to high latitudes. PLOS Genetics 13, e1006530.

Goslin K, Zheng B, Serrano-Mislata A, et al. 2017. Transcription factor interplay between LEAFY and APETALA1/CAULIFLOWER during floral initiation. Plant Physiology 174, 1097-1109.

Goto K, Meyerowitz EM. 1994. Function and regulation of the Arabidopsis floral homeotic gene PISTILLATA. Genes \& Development 8, 1548-1560.

Haecker A, Gross-Hardt R, Geiges B, Sarkar A, Breuninger H, Herrmann M, Laux T. 2004. Expression dynamics of WOX genes mark cell fate decisions during early embryonic patterning in Arabidopsis thaliana. Development 131, 657-668.

Havlícková L, Jozová E, Klíma M, Kucera V, Curn V. 2014. Detection of self-incompatible oilseed rape plants (Brassica napus L.) based on molecular markers for identification of the class I S haplotype. Genetics and Molecular Biology 37, 556-559.

Hayama R, Yokoi S, Tamaki S, Yano M, Shimamoto K. 2003. Adaptation of photoperiodic control pathways produces short-day flowering in rice. Nature 422, 719-722.

Heijmans K, Ament K, Rijpkema AS, Zethof J, Wolters-Arts M, Gerats T, Vandenbussche M. 2012. Redefining C and D in the petunia ABC. The Plant Cell 24, 2305-2317.

Hiscock SJ, Tabah DA. 2003. The different mechanisms of sporophytic self-incompatibility. Philosophical Transactions of the Royal Society B: Biological Sciences 358, 1037-1045.

Honma T, Goto K. 2001. Complexes of MADS-box proteins are sufficient to convert leaves into floral organs. Nature 409, 525-529.

Huang C, Sun H, Xu D, et al. 2018. ZmCCT9 regulates maize flowering time. Proceedings of the National Academy of Sciences, USA 115 , E334-E341.

Hubbard L, McSteen P, Doebley J, Hake S. 2002. Expression patterns and mutant phenotype of teosinte branched 1 correlate with growth suppression in maize and teosinte. Genetics 162, 1927-1935.

Hunt HV, Denyer K, Packman LC, Jones MK, Howe CJ. 2010. Molecular basis of the waxy endosperm starch phenotype in broomcorn millet (Panicum miliaceum L.). Molecular Biology and Evolution 27, 1478-1494.

Huq E, Tepperman JM, Quail PH. 2000. GIGANTEA is a nuclear protein involved in phytochrome signaling in Arabidopsis. Proceedings of the National Academy of Sciences, USA 97, 9789-9794.

Igic B, Kohn JR. 2006. The distribution of plant mating systems: study bias against obligately outcrossing species. Evolution 60, 1098-1103.

Igic B, Lande R, Kohn JR. 2008. Loss of self-incompatibility and its evolutionary consequences. International Journal of Plant Sciences 169, 93-104.

Ikeda-Kawakatsu K, Maekawa M, Izawa T, Itoh J, Nagato Y. 2012. ABERRANT PANICLE ORGANIZATION 2/RFL, the rice ortholog of Arabidopsis $\angle E A F Y$, suppresses the transition from inflorescence meristem to floral meristem through interaction with APO1. The Plant Journal 69 , $168-180$

Irish V. 2017. The ABC model of floral development. Current Biology 27, R887-R890.

Itoh H, Nonoue Y, Yano M, Izawa T. 2010. A pair of floral regulators sets critical day length for $\mathrm{Hd} 3 \mathrm{a}$ florigen expression in rice. Nature Genetics 42 635-638.

Iwano M, Ito K, Fujii S, et al. 2015. Calcium signalling mediates self-incompatibility response in the Brassicaceae. Nature Plants 1, 15128.

Iwano M, Takayama S. 2012. Self/non-self discrimination in angiosperm self-incompatibility. Current Opinion in Plant Biology 15, 78-83.

Iwata T, Nagasaki O, Ishii HS, Ushimaru A. 2012. Inflorescence architecture affects pollinator behaviour and mating success in Spiranthes sinensis (Orchidaceae). New Phytologist 193, 196-203.

Jack T, Brockman LL, Meyerowitz EM. 1992. The homeotic gene APETALA3 of Arabidopsis thaliana encodes a MADS box and is expressed in petals and stamens. Cell 68, 683-697. 
Jofuku KD, den Boer BG, Van Montagu M, Okamuro JK. 1994. Control of Arabidopsis flower and seed development by the homeotic gene APETALA2. The Plant Cell 6, 1211-1225.

Kaothien-Nakayama P, Isogai A, Takayama S. 2010. Self-incompatibility systems in flowering plants. In: Pua E, Davey M, eds. Plant developmental biology - biotechnological perspectives. Berlin: Springer Berlin Heidelberg, 459-485.

Kardailsky I, Shukla VK, Ahn JH, Dagenais N, Christensen SK, Nguyen JT, Chory J, Harrison MJ, Weigel D. 1999. Activation tagging of the floral inducer FT. Science 286, 1962-1965.

Kaufmann K, Muiño JM, Jauregui R, Airoldi CA, Smaczniak C, Krajewski P, Angenent GC. 2009. Target genes of the MADS transcription factor SEPALLATA3: integration of developmental and hormonal pathways in the Arabidopsis flower. PLoS Biology 7, e1000090.

Kebrom TH, Brutnell TP. 2015. Tillering in the sugary1 sweet corn is maintained by overriding the teosinte branched1 repressive signal. Plant Signaling \& Behavior 10, e1078954.

Kempin SA, Savidge B, Yanofsky MF. 1995. Molecular basis of the cauliflower phenotype in Arabidopsis. Science 267, 522-525.

Kitashiba H, Nasrallah JB. 2014. Self-incompatibility in Brassicaceae crops: lessons for interspecific incompatibility. Breeding Science 64, 23-37.

Kobayashi Y, Kaya H, Goto K, Iwabuchi M, Araki T. 1999. A pair of related genes with antagonistic roles in mediating flowering signals. Science 286, 1960-1962.

Kojima S, Takahashi Y, Kobayashi Y, Monna L, Sasaki T, Araki T, Yano M. 2002. Hd3a, a rice ortholog of the Arabidopsis FT gene, promotes transition to flowering downstream of $\mathrm{Hd} 1$ under short-day conditions. Plant \& Cell Physiology 43, 1096-1105.

Komiya R, Ikegami A, Tamaki S, Yokoi S, Shimamoto K. 2008. Hd3a and RFI1 are essential for flowering in rice. Development 135, 767-774.

Koo BH, Yoo SC, Park JW, Kwon CT, Lee BD, An G, Zhang Z, Li J, Li Z, Paek NC. 2013. Natural variation in OsPRR37 regulates heading date and contributes to rice cultivation at a wide range of latitudes. Molecular Plant 6, 1877-1888.

Koseva B, Crawford DJ, Brown KE, Mort ME, Kelly JK. 2017. The genetic breakdown of sporophytic self-incompatibility in Tolpis coronopifolia (Asteraceae). New Phytologist 216, 1256-1267.

Krizek BA, Fletcher JC. 2005. Molecular mechanisms of flower development: an armchair guide. Nature Reviews. Genetics 6, 688-698.

Kuhn DN, Livingstone DS III, Richards JH, Manosalva P, Van den Berg N, Chambers AH. 2019. Application of genomic tools to avocado (Persea americana) breeding: SNP discovery for genotyping and germplasm characterization. Scientia Horticulturae 246, 1-11.

Kyozuka J, Konishi S, Nemoto K, Izawa T, Shimamoto K. 1998. Downregulation of $R F L$, the $F L O / L F Y$ homolog of rice, accompanied with panicle branch initiation. Proceedings of the National Academy of Sciences, USA 95, 1979-82.

Labate JA, Robertson LD, Baldo AM, Björkman T. 2006. Inflorescence identity gene alleles are poor predictors of inflorescence type in broccoli and cauliflower. Journal of the American Society for Horticultural Science 131, 667-673.

Lanaud C, Fouet O, Legavre T, et al. 2017. Deciphering the Theobroma cacao self-incompatibility system: from genomics to diagnostic markers for self-compatibility. Journal of Experimental Botany 68, 4775-4790.

Langewisch T, Zhang H, Vincent R, Joshi T, Xu D, Bilyeu K. 2014. Major soybean maturity gene haplotypes revealed by SNPViz analysis of 72 sequenced soybean genomes. PLoS One 9, e94150.

Lao X, Suwabe K, Niikura S, Kakita M, Iwano M, Takayama S. 2014. Physiological and genetic analysis of $\mathrm{CO}_{2}$-induced breakdown of self-incompatibility in Brassica rapa. Journal of Experimental Botany 65, 939-951.

Lescot T. 2010. The genetic diversity of banana in figures. FruiTrop $\mathbf{1 7 7}$, 48-52.

Li YH, Zhao SC, Ma JX, et al. 2013. Molecular footprints of domestication and improvement in soybean revealed by whole genome re-sequencing. BMC Genomics 14, 579.

Liljegren SJ, Gustafson-Brown C, Pinyopich A, Ditta GS, Yanofsky MF. 1999. Interactions among APETALA1, LEAFY, and TERMINAL FLOWER1 specify meristem fate. The Plant Cell 11, 1007-1018.
Lippman ZB, Cohen O, Alvarez JP, Abu-Abied M, Pekker I, Paran I, Eshed Y, Zamir D. 2008. The making of a compound inflorescence in tomato and related nightshades. PLoS Biology 6, e288.

Litt A. 2007. An evaluation of A-function: evidence from the APETALA1 and APETALA2 gene lineages. International Journal of Plant Sciences 168, 73-91.

Liu B, Watanabe S, Uchiyama T, et al. 2010. The soybean stem growth habit gene Dt1 is an ortholog of Arabidopsis TERMINAL FLOWER1. Plant Physiology 153, 198-210.

Liu C, Teo ZW, Bi Y, Song S, Xi W, Yang X, Yin Z, Yu H. 2013. A conserved genetic pathway determines inflorescence architecture in Arabidopsis and rice. Developmental Cell 24, 612-622.

Liu Z, Zhang D, Liu D, Li F, Lu H. 2013. Exon skipping of AGAMOUS homolog PrseAG in developing double flowers of Prunus lannesiana (Rosaceae). Plant Cell Reports 32, 227-237.

Loor Solorzano RG, Fouet O, Lemainque A, Pavek S, Boccara M, Argout X, Amores F, Courtois B, Risterucci AM, Lanaud C. 2012. Insight into the wild origin, migration and domestication history of the fine flavour Nacional Theobroma cacao L. variety from Ecuador. PLoS One 7, e48438.

Lowman AC, Purugganan MD. 1999. Duplication of the Brassica oleracea APETALA1 floral homeotic gene and the evolution of domesticated cauliflower. Journal of Heredity 90, 514-520.

Luo D, Carpenter R, Copsey L, Vincent C, Clark J, Coen E. 1999. Control of organ asymmetry in flowers of Antirrhinum. Cell 99, 367-376.

Luo D, Carpenter R, Vincent C, Copsey L, Coen E. 1996. Origin of floral asymmetry in Antirrhinum. Nature 383, 794-799.

Mahrez W, Arellano MS, Moreno-Romero J, Nakamura M, Shu H, Nanni P, Köhler C, Gruissem W, Hennig L. 2016. H3K36ac is an evolutionary conserved plant histone modification that marks active genes. Plant Physiology 170, 1566-1577.

Mandel MA, Gustafson-Brown C, Savidge B, Yanofsky MF. 1992. Molecular characterization of the Arabidopsis floral homeotic gene APETALA1. Nature 360, 273-277.

Martínez-Gómez P, Sánchez-Pérez R, Dicenta F. 2006. Fruit development in almond. Acta Horticulturae 726, 241-246.

McClure B. 2006. New views of S-RNase-based self-incompatibility. Current Opinion in Plant Biology 9, 639-646.

McClure B. 2012. Plant self-incompatibility: ancient system becomes a new tool. Current Biology 22, R86-R87.

McGarry RC, Prewitt SF, Culpepper S, Eshed Y, Lifschitz E, Ayre BG. 2016. Monopodial and sympodial branching architecture in cotton is differentially regulated by the Gossypium hirsutum SINGLE FLOWER TRUSS and SELF-PRUNING orthologs. New Phytologist 212, 244-258.

McKey D, Elias M, Pujol B, Duputié A. 2010. The evolutionary ecology of clonally propagated domesticated plants. New Phytologist 186, 318-332.

Michaels SD, Amasino RM. 1999. FLOWERING LOCUS C encodes a novel MADS domain protein that acts as a repressor of flowering. The Plant Cell 11, 949-956.

Mimida N, Goto K, Kobayashi Y, Araki T, Ahn JH, Weigel D, Murata M, Motoyoshi F, Sakamoto W. 2001. Functional divergence of the TFL1-like gene family in Arabidopsis revealed by characterization of a novel homologue. Genes to Cells 6, 327-336.

Miller AJ, Gross BL. 2011. From forest to field: perennial fruit crop domestication. American Journal of Botany 98, 1389-1414.

Molinero-Rosales N, Jamilena M, Zurita S, Gómez P, Capel J, Lozano R. 1999. FALSIFLORA, the tomato orthologue of FLORICAULA and $L E A F Y$, controls flowering time and floral meristem identity. The Plant Journal 20, 685-693.

Morel P, Heijmans K, Rozier F, Zethof J, Chamot S, Bento SR, Vialette-Guiraud A, Chambrier P, Trehin C, Vandenbussche M. 2017. Divergence of the floral A-function between an asterid and a rosid species. The Plant Cell 29, 1605-1621.

Moyroud E, Glover BJ. 2017. The evolution of diverse floral morphologies. Current Biology 27, R941-R951.

Müller NA, Wijnen CL, Srinivasan A, et al. 2016. Domestication selected for deceleration of the circadian clock in cultivated tomato. Nature Genetics 48, 89-93. 
Müller NA, Zhang L, Koornneef M, Jiménez-Gómez JM. 2018 Mutations in EID1 and LNK2 caused light-conditional clock deceleration during tomato domestication. Proceedings of the National Academy of Sciences, USA 115, 7135-7140.

Ockendon DJ. 1974. Distribution of self-incompatibility alleles and breeding structure of open-pollinated cultivars of Brussels sprouts. Heredity 33, 159-171.

Parcy F, Nilsson O, Busch MA, Lee I, Weigel D. 1998. A genetic framework for floral patterning. Nature 395, 561-566.

Park DH, Somers DE, Kim YS, Choy YH, Lim HK, Soh MS, Kim HJ, Kay SA, Nam HG. 1999. Control of circadian rhythms and photoperiodic flowering by the Arabidopsis G/GANTEA gene. Science 285, 1579-1582.

Pelaz S, Ditta GS, Baumann E, Wisman E, Yanofsky MF. 2000. B and C floral organ identity functions require SEPALLATA MADS-box genes. Nature 405, 200-203.

Pelaz S, Tapia-López R, Alvarez-Buylla ER, Yanofsky MF. 2001. Conversion of leaves into petals in Arabidopsis. Current Biology 11, 182-184.

Perez-Rodriguez M, Jaffe FW, Butelli E, Glover BJ, Martin C. 2005. Development of three different cell types is associated with the activity of a specific MYB transcription factor in the ventral petal of Antirrhinum majus flowers. Development 132, 359-370.

Pinyopich A, Ditta GS, Savidge B, Liljegren SJ, Baumann E, Wisman E, Yanofsky MF. 2003. Assessing the redundancy of MADS-box genes during carpel and ovule development. Nature 424, 85-88.

Pekkala N, Knott KE, Kotiaho JS, Nissinen K, Puurtinen M. 2014. The effect of inbreeding rate on fitness, inbreeding depression and heterosis over a range of inbreeding coefficients. Evolutionary Applications 7, 1107-1119.

Pnueli L, Carmel-Goren L, Hareven D, Gutfinger T, Alvarez J, Ganal M, Zamir D, Lifschitz E. 1998. The SELF-PRUNING gene of tomato regulates vegetative to reproductive switching of sympodial meristems and is the ortholog of CEN and TFL1. Development 125, 1979-1989.

Prusinkiewicz P, Erasmus Y, Lane B, Harder LD, Coen E. 2007. Evolution and development of inflorescence architectures. Science 316, 1452-1456.

Purugganan MD, Boyles AL, Suddith Jl. 2000. Variation and selection at the CAULIFLOWER floral homeotic gene accompanying the evolution of domesticated Brassica oleracea. Genetics 155, 855-862.

Putterill J, Robson F, Lee K, Simon R, Coupland G. 1995. The CONSTANS gene of Arabidopsis promotes flowering and encodes a protein showing similarities to zinc finger transcription factors. Cell 80, 847-857.

Ratcliffe OJ, Bradley DJ, Coen ES. 1999. Separation of shoot and floral identity in Arabidopsis. Development 126, 1109-1120.

Reardon W, Fitzpatrick DA, Fares MA, Nugent JM. 2009. Evolution of flower shape in Plantago lanceolata. Plant Molecular Biology 71, 241-250.

Santos ES, Cerqueira-Silva CB, Mori GM, Ahnert D, Mello DL, Pires JL, Corrêa RX, de Souza AP. 2015. Genetic structure and molecular diversity of cacao plants established as local varieties for more than two centuries: the genetic history of Cacao plantations in Bahia, Brazil. PLoS One 10, e0145276.

Sassa H. 2016. Molecular mechanism of the S-RNase-based gametophytic self-incompatibility in fruit trees of Rosaceae. Breeding Science $\mathbf{6 6}$, 116-121.

Saumitou-Laprade P, Vernet P, Vekemans X, et al. 2017. Elucidation of the genetic architecture of self-incompatibility in olive: evolutionary consequences and perspectives for orchard management. Evolutionary Applications 10, 867-880.

Schilling S, Pan S, Kennedy A, Melzer R. 2018. MADS-box genes and crop domestication: the jack of all traits. Journal of Experimental Botany 69, 1447-1469.

Sehgal N, Singh S. 2018. Progress on deciphering the molecular aspects of cell-to-cell communication in Brassica self-incompatibility response. 3 Biotech 8, 347.

Serrano-Mislata A, Goslin K, Zheng B, Rae L, Wellmer F, Graciet E, Madueño F. 2017. Regulatory interplay between LEAFY, APETALA1/CAULIFLOWER and TERMINAL FLOWER1: new insights into an old relationship. Plant Signaling \& Behavior 12, e1370164.
Sessions A, Yanofsky MF, Weigel D. 2000. Cell-cell signaling and movement by the floral transcription factors LEAFY and APETALA1. Science $\mathbf{2 8 9}$, 779-782.

Shannon S, Meeks-Wagner DR. 1993. Genetic interactions that regulate inflorescence development in Arabidopsis. The Plant Cell 5, 639-655.

Smith LB, King GJ. 2000. The distribution of BoCAL-a alleles in Brassica oleracea is consistent with a genetic model for curd development and domestication of the cauliflower. Molecular Breeding 6, 603-613.

Smyth DR. 2018. Evolution and genetic control of the floral ground plan. New Phytologist 220, 70-86.

Song YH, Shim JS, Kinmonth-Schultz HA, Imaizumi T. 2015. Photoperiodic flowering: time measurement mechanisms in leaves. Annual Review of Plant Biology 66, 441-464.

Spiegel-Roy P. 1986. Domestication of fruit trees. Developments in Agricultural and Managed Forest Ecology 16, 201-211.

Stewart D, Graciet E, Wellmer F. 2016. Molecular and regulatory mechanisms controlling floral organ development. FEBS Journal 283, 1823-1830.

Studer A, Zhao Q, Ross-Ibarra J, Doebley J. 2011. Identification of a functional transposon insertion in the maize domestication gene tb1. Nature Genetics 43, 1160-1163.

Su S, Xiao W, Guo W, et al. 2017. The CYCLOIDEA-RADIALIS module regulates petal shape and pigmentation, leading to bilateral corolla symmetry in Torenia fournieri (Linderniaceae). New Phytologist 215, 1582-1593.

Sun Y, Fan Z, Li X, Li J, Yin H. 2014. The APETALA1 and FRUITFUL homologs in Camellia japonica and their roles in double flower domestication. Molecular Breeding 33, 821-834.

Teo ZW, Song S, Wang YQ, Liu J, Yu H. 2014. New insights into the regulation of inflorescence architecture. Trends in Plant Science 19, 158-165.

Theissen G, Melzer R. 2007. Molecular mechanisms underlying origin and diversification of the angiosperm flower. Annals of Botany 100, 603-619.

Theißen G, Melzer R, Rümpler F. 2016. MADS-domain transcription factors and the floral quartet model of flower development: linking plant development and evolution. Development 143, 3259-3271.

Theißen G, Saedler H. 2001. Floral quartets. Nature 409, 469-471.

Tian Z, Wang X, Lee R, Li Y, Specht JE, Nelson RL, McClean PL, Qiu L, Ma J. 2010. Artificial selection for determinate growth habit in soybean. Proceedings of the National Academy of Sciences, USA 107, 8563-8568.

Ueda M, Zhang Z, Laux T. 2011. Transcriptional activation of Arabidopsis axis patterning genes WOX8/9 links zygote polarity to embryo development. Developmental Cell 20, 264-270.

Valverde F, Mouradov A, Soppe W, Ravenscroft D, Samach A Coupland G. 2004. Photoreceptor regulation of CONSTANS protein in photoperiodic flowering. Science 303, 1003-1006.

Vieira J, Fonseca NA, Vieira CP. 2009. RNase-based gametophytic self-incompatibility evolution: questioning the hypothesis of multiple independent recruitments of the S-pollen gene. Journal of Molecular Evolution 69, 32-41.

Wagner D, Sablowski RW, Meyerowitz EM. 1999. Transcriptional activation of APETALA1 by LEAFY. Science $\mathbf{2 8 5}, 582-584$.

Wang B, Smith SM, Li J. 2018. Genetic regulation of shoot architecture. Annual Review of Plant Biology 69, 437-468.

Weberling F. 1989. Structure and evolutionary tendencies of inflorescences in the Leguminosae. Monographs in Systematic Botany from the Missouri Botanical Garden 29, 35-58.

Wei X, Xu J, Guo H, Jiang L, Chen S, Yu C, Zhou Z, Hu P, Zhai H, Wan J. 2010. DTH8 suppresses flowering in rice, influencing plant height and yield potential simultaneously. Plant Physiology 153, 1747-1758.

Weigel D, Alvarez J, Smyth DR, Yanofsky MF, Meyerowitz EM. 1992. LEAFY controls floral meristem identity in Arabidopsis. Cell 69, 843-859.

Weigel D, Meyerowitz EM. 1994. The ABCs of floral homeotic genes. Cell 78, 203-209.

Weigel D, Nilsson O. 1995. A developmental switch sufficient for flower initiation in diverse plants. Nature $\mathbf{3 7 7}$, 495-500.

Wigge PA, Kim MC, Jaeger KE, Busch W, Schmid M, Lohmann JU, Weigel D. 2005. Integration of spatial and temporal information during floral induction in Arabidopsis. Science 309, 1056-1059. 
Wils CR, Kaufmann K. 2017. Gene-regulatory networks controlling inflorescence and flower development in Arabidopsis thaliana. Biochimica et Biophysica Acta 1860, 95-105.

Wu F, Shi X, Lin X, Liu Y, Chong K, Theißen G, Meng Z. 2017. The ABCs of flower development: mutational analysis of $A P 1 / F U L$-like genes in rice provides evidence for a homeotic (A)-function in grasses. The Plant Journal 89, 310-324.

Wu X, Chory J, Weigel D. 2007. Combinations of WOX activities regulate tissue proliferation during Arabidopsis embryonic development. Developmental Biology 309, 306-316.

Wu X, Dabi T, Weigel D. 2005. Requirement of homeobox gene STIMPY/ WOX9 for Arabidopsis meristem growth and maintenance. Current Biology 15, 436-440.

Wünsch A, Hormaza JI. 2004. Molecular evaluation of genetic diversity and S-allele composition of local Spanish sweet cherry (Prunus avium L.) cultivars. Genetic Resources and Crop Evolution 51, 635-641.

Wyatt R. 1982. Inflorescence architecture: how flower number, arrangement, and phenology affect pollination and fruit-set. American Journal of Botany 69, 585-594.

Xiao Z, Han F, Hu Y, et al. 2019. Overcoming cabbage crossing incompatibility by the development and application of self-compatibility-QTLspecific markers and genome-wide background analysis. Frontiers in Plant Science 10, 189.

Xue W, Xing Y, Weng X, et al. 2008. Natural variation in Ghd7 is an important regulator of heading date and yield potential in rice. Nature Genetics 40, 761-767.
Yano M, Katayose Y, Ashikari M, et al. 2000. Hd1, a major photoperiod sensitivity quantitative trait locus in rice, is closely related to the Arabidopsis flowering time gene CONSTANS. The Plant Cell 12, 2473-2484.

Yanofsky MF, Ma H, Bowman JL, Drews GN, Feldmann KA, Meyerowitz EM. 1990. The protein encoded by the Arabidopsis homeotic gene agamous resembles transcription factors. Nature 346, 35-39.

Ye L, Wang B, Zhang W, Shan H, Kong H. 2016. Gains and losses of cis-regulatory elements led to divergence of the Arabidopsis APETALA1 and CAULIFLOWER duplicate genes in the time, space, and level of expression and regulation of one paralog by the other. Plant Physiology 171, 1055-1069.

Yeager AF. 1927. Determinate growth in the tomato. Journal of Heredity 18, 263-265.

Zhai H, Lü S, Wang Y, et al. 2014. Allelic variations at four major maturity $E$ genes and transcriptional abundance of the $E 1$ gene are associated with flowering time and maturity of soybean cultivars. PLoS One $\mathbf{9}$, e97636.

Zheng H, Kawabata S, Zheng H, Kawabata S. 2017. Identification and validation of new alleles of FALSIFLORA and COMPOUND INFLORESCENCE genes controlling the number of branches in tomato inflorescence. International Journal of Molecular Sciences 18, 1572.

Zhu S, Wang J, Cai M, et al. 2017. The OSHAPL1-DTH8-Hd1 complex functions as the transcription regulator to repress heading date in rice. Journal of Experimental Botany 68, 553-568.

Zhu Z, Tan L, Fu Y, Liu F, Cai H, Xie D, Wu F, Wu J, Matsumoto T, Sun C. 2013. Genetic control of inflorescence architecture during rice domestication. Nature Communications 4, 2200. 